\title{
Renewal Under Modern Islamic Jurisprudence (Fiqh) (Sami Hmoud as a sample)
}

\author{
Dr. Husain Mohammad Ahmed Alrababah \\ AlBalqa Applied University \\ Dr. Yusuf Mohammad Ahmed Alrababah \\ Jerash Private University \\ Dr.Nedal Hasan FALAH ALMomani \\ Al Balqa Applied University \\ Ibrahim Mohammad Rababah \\ The Ministry of Education of jordan
}

\begin{abstract}
The Almighty Allah had completed his religion, made the Islamic law for us that it includes principles and general rules which are suitable for application all time and place; it is the achieved happiness of mankind in all time. It is wide enough for each incident; the life is in permanent development and continuous, it means that its issues remain renewed; this is the statement of Allah Judgment, and discovering it in all these developments, so that the Islamic law remains the ruling of the acts of slaves of Allah. There is no doubt that people need someone who renews for them everything related to the affairs of their daily lives and treats their general problems from the jurisprudential side that is compatible with their daily lives. Therefore, there must be a number of jurists to be well-versed in Islamic jurisprudence, to go deeply into understanding Islamic religion texts and goals of Islam to able how inference provisions of Islamic Shari'ah which correspond to the developments of daily lives in order to keep up with the times and its developments, it is urgent in most areas of life and it is more urgent in the field of Islamic financial transactions or what is known as the Islamic economy as the development and renewal of the global financial and business market requires a group of renewed person $\mathrm{s}$ under Islamic financial jurisprudence to keep up with the rapid developments in this field, one of the famous renewed person s is Dr. Sami Hmoud.
\end{abstract}

Keywords: Islamic Jurisprudence,Fiqh

DOI: $10.7176 / \mathrm{JPCR} / 46-04$

Publication date: November $30^{\text {th }} 2019$

\section{Importance of Research}

The importance of the subject in many things, the most significant are:

1- The topic addresses issues related to the vital aspect of daily Muslim life from the aspect of Islamic economy.

2- To contribute in the consideration of issues that related to Islamic financial transactions.

3- To keep up with modern developments of recent developments related to wealth, Islamic finance, and Islamic economy.

\section{Research objectives}

1. To highlight the perfection of Islamic law, its comprehensiveness, validity for every time and place, and accompaniment the modern developments and jurisprudential issues, especially in the field of Islamic economics.

2. Statement of the role of renewed person $\mathrm{s}$ in the jurisprudence of the Islamiceconomy.

3. Statement of the importance of renewal in the Islamic economy according to the requirements of the times.

4. To highlight the role of renewed person $\mathrm{s}$ in the issues of Islamic economics.

\section{Research Problem}

To arise from time to time issues and developments in the field of Islamic economics, the need to find an urgent situation, the injunction of the law in accordance with the principles and rules of Islamic jurisprudence, and finding appropriate solutions to these issues.

\section{Research Methodology}

The approach has been used in this research is based on the inductive method, the study of rules relating to 
financial issues, Islamic transactions, and the balance was made between the opinions of the old jurists and renewed person s in contemporary time, and highlighting the role of Dr. Sami Hmoud in this field. It shows the need for renewal in financial cases.

The First Topic: Definition of renewal, its importance, and the need it in financial transactions

Renewal is a divine ordinance way in this religion and fits with it is known that Almighty Allah has sealed the prophets Muhammad (4) peace be upon him, the scholars who renew this religion to the nation are his proxies and the heirs of his leaders - ( raise for this community at the end of every hundred years the one who will renovate its religion for it). (1) In this Hadith glad tiding, it is promised the nation in glad tidings by the Prophet Mohammad ( him- It is not free of renewed person s, it is the promise of Allah. It includes Hadith important legitimate aspect that is the request of the nation, especially those capable of scholars and faith to perform the entrusted role to them. The renewal will be at their hands, the renewed person s do not come down from heaven.

\section{Definition of renewal:}

Al-FayrouzAbadi mentioned in al-Qamos and al-Zubairi in Taj al-Aroos: (Diligence(ijtihad) - Diligence(ijtihad) in the matter), and the renewal is the Diligence(ijtihad) to get out from the old form to new form, either by taking out it recently or by finding what in old, to highlight its secrets and mysteries, or its formalization in an acceptable and realistic manner.

In Language: as mentioned al-Umawi in al-Ehkam is: Ability to do to achieve something is necessitating hardship.(2)

As definition: It is as defined by al-Kamal Ibn al-Hamam in al-Tahreer: The effort of the jurist in the collection of a legitimate judgment, whether rational or traditional, categorical or hypothetical.(3)

The importance of renewal under Islamic Jurisprudence (Fiqh):

The issue of renewal under Islamic jurisprudence (Fiqh) is associated with Diligence(ijtihad), it's based on flexibility and keeping up with Islamic law of different ages and times, this issue was kept up with the reality of Muslims from the beginning of the Proclamation of the Message until the modern time, it will remain so until Allah reclaims it and everything on it. It called for the need, Muslims do not dispense with the developments and scientific progress in various fields, it provided that this is done in accordance with the Shariah rules derived from the Quran and the Sunnah of Allah's Messenger.

It is known that the companions - may Allah be pleased with them - after the era of prophecy, they tried as much as they could to resolve the problems they face in their lives. If they faced a new incident, and they did not find a rule in the Quran or in the Sunnah, so they tried to Diligence(ijtihad), they were famous in that field; they tried as much as they could to resolve the problems that they faced in their lives, they facilitated the way of Diligence(ijtihad)for those who came after them because they follow their way, set the rules, put the foundations, established the Usool, wrote Islamic jurisprudence, saved the book and the valuable publications for us. The jurisprudence is anrenewal by renewing justice or jurisprudence issues.

Diligence (ijtihad) and research in the provisions of justice or jurisprudence issues have a great role in the renewal and development of jurisprudence in the souls, and in the reality of people's lives. Diligence (ijtihad) in the search for the provisions of justice or jurisprudence issues lead to Faqīh and Mujtahid may resort to authorship and classification in cases and issues that were not previously codified in the first Islamic Books in Fiqh, such as banking transactions, insurance issues, and contemporary medical issues and others.

There is no doubt that this matter enriches the Islamic jurisprudence movement and growing and renewal towards a broader response to the needs of people and society.

The justice or jurisprudence issues (Fiqh) and Fatwa will remain the broad arena for the growth of the rule of diligence (ijtihad), enriches our Islamic thought with new jurisprudential views. (4)

This large spread compared to its short chronological age, it has raised a great demand for some areas that must be contained in the model Islamic Bank or the structure of the Islamic Bank and one of them is Shari'a supervision or the Shari'a Board that monitors the Bank's business in terms of legitimacy.

According to Geert Bussiot, Deutsche Bank's regional head for the Middle East that Islamic finance creates crises for itself, Fatwa do not gain credibility unless written by a respected scholar " Âlim ", so banks compete

\footnotetext{
(1)Narrated by Abu Dawud (no. 4291) and transmitted (corrected) by al-Sakhawi in Makassed al-Hasanah (149) and al-Albani in al-Silsilah al-Saheehah (No. 599).

${ }^{(2)}$ See the word "Effort" in language: al-Mujmal 141, al-Sehah 2/402, TahtheebAlloga 6/37, al-Moheet fi alloga 3/369, Mufradatalfath alQuraan 208, al-Nehaia fi Gareeb al-Hadith wa al-Athar 1/319, al-takmelawa al-thailwa al-Selah 2/215, Asas al-Balaga 67, Lesan al-Arab 2/395, al-Musbah al-Muneer 112, al-Qamos al-Moheet 351, Taj al-Aros 4/407, and al-Mu'jam al-waseet 142 all of them are : "effort".

${ }^{(3)}$ Al-Kamal Ibn Hammam (see Editorial, p. 23.)

( 4 'Fiqh Forum, FadlallahMumtaz, The importance of renewal jurisprudence.
} http://fiqh.islammessage.com/NewsDetails.aspx?id=8923. 
for the few available.(1)

One of the most important challenges to its development with rapid growth is the various interpretations of Islamic law and the absence of standardization in many aspects of Sharia that leaving the field open for the standing questions in this sector. In addition to the lack of religious scholars who are able to evaluate new financial products.

Although there are about 150 Islamic scholars qualified to enter the boards of Islamic financial institutions, but few of them have the knowledge that banks and international financial institutions need and few of them are in the process of creating or inventing renewal products, the introduction of a new idea makes this product a new dimension and a new need accepted by customers again. (2)

In recognition of the logic of change imposed by the movement of life and the different circumstances of time and place, as required by developments known to Islamic societies, Islamic jurisprudence must be linked to the reality of living, interacting with the transformations that the world is experiencing at this stage in an unprecedented manner with the variables that are capable of dealing with its renewed problems.

In reviewing the inherited jurisprudence (Fiqh), it is clear to us that it does not meet the needs of the Muslim who is facing issues and problems that pose many questions, make him look forward to a way out of the civilization crisis that he finds himself in its circles, it requires the generation of "new jurisprudenceinherited (Figh)", he Is able to adapt to this changing reality with its various challenges, and its renewal in a way that provides for contemporary jurisprudence (Fiqh).(3)

These transformations are accelerating towards the introduction of principles and the Islamic economy according to financial transactions locally and globally to require contemporary jurists the need to activate and renew the tools of Islamic jurisprudence to more efficiently absorb those rapid developments in the Islamic financial sector in various sectors of banking, financial and investment including insurance and financial markets.(4)

\section{Renewal controls}

Renewal and creativity are one of the points raised in Islamic law and we talk here about the scholars and Fuqaha, They are developing rules and standards for the renewed person andMujtahid. It is the thing that closes the door to the thinkers and creations to devise new tools for the Islamic economy which in the same order set limits and conditions that limit renewal, and perhaps monopolize themselves.

The rules of renewal as presented by al-Khulaifican be divided according to their main approaches to the following:

Regards of renewal In view of such renewal (renewal eligibility), "It is with our recognition of the need for renewal in the Islamic sciences in general and the jurisprudence of financial transactions in particular, but must take into account the duty of eligibility of the leader of the place of renewal, it should not address renewal the common people and the like of fools, the common people and their ilk are ignorant of those who dare to doFatwa, and they break into the walls of the law without jurisprudence (Fiqh) or knowledge perhaps with a few pious and religious."

Khulaifi presents the conditions of the diligent according to the works of the Scholars of the Principles of Jurisprudence as follows:Knowledge of verses of judgments, knowing the rules of Hadith, Knowledge of (Naskh) abrogation, it refers to the theory in Islamic legal exegesis whereby seemingly contradictory material within, or between, the two primary sources of Islamic law, from the Quran and the Sunnah, knowing the issues of unanimity and its location, Knowing the object of the measurement and its terms, explaining the provisions and ways of deriving them from the texts, people's interests, and the fundamentals of Shari'a.

The knowledge of Arabic language science in language (al-lughah), morphology (at-tașrīf) and syntax (annahw ), lexicon, derivation, knowledge of the principles of jurisprudence, andfinally to know the general purposes of Sharia. It is difficult to comprehend this knowledge surrounded by a great briefing; the fundamentalists may have overlooked something important that each individual has his or her own competence that the dialogue and discussion language must be present in any society.

If the eligibility person exists in strive and renewal, he may have made a mistake although he was familiar with previous knowledge. Who will fix the error and highlight it? The renewed person must be part of a group that revises and matured the dialogue.

These principles and methodological principles are summarized in the following principles:

First: caring of Islamic texts:

\footnotetext{
(1) Who is responsible for renewal in Islamic transactions? Research Center Islamic Jurisprudence - https://kantakji.com/researchdevelopment.

(2)The same previous reference.

(3) Principles of Renewal of Islamic Jurisprudence Dr. MahrousBrikhttp://www.hamassa.com/2017/08/12.

(4) Renewal in Jurisprudence of Contemporary Financial Transactions, Dr. Riyadh Mansour Al-Khulaifi / Director General of the Office of the International Forensic Advisor for Consulting and External Legal Auditing - Kuwait.
} 
The jurist must consider the legal texts related to emerging financial transactions and reinvest them in accordance with fundamental rules in induction and deduction, that achieving the answer of justice issues responsible for it, the Islamic texts are the basic source of injunctions of law on the difference in time and place, the diligent must rely on it and he does not exceed his eyes only for necessity, what known in the text and meaning with the righteous forefathers, imams, and justice issues (Fuqaha).Allah Almighty says: "We have not neglected in the Register a thing". (1) and also Allah Almighty says: "And we have sent down to you the Book as clarification for all things and as guidance and mercy and good tidings for the Muslims". (2)

In the opinion of al-Khulaifi that the failure to consider texts or leniency in the reliability of the collection and study and devolution requires the violation of the legitimate ruling of financial treatment, and then get from the corruption of religious and mundane according to that default and breach,corresponding to the text optimally requires injury to the right, the collection of religious interests and mundane, the Messenger of Allah, may Allah bless him and grant him peace, said, "I have left two matters with you. As long as you hold to them, you will not go the wrong way. They are the Book of Allah and the Sunna of His Prophet." In this Zarkashi said: "And on the jurisprudence self of the right talent, follow the words in the Qur'an and the Sunnah, and extract meanings from them, and whoever made it his presence, he found it full patrimony the sea, which did not bleed."

The fact of taking care of Shariah texts and their jurisprudence isbased on two types of jurisprudence: The jurisprudence of connotation text and the appropriate jurisprudence of the text.

Second: Caring for the rules of development and its tools.

The optimal investment of texts can be achieved only if it is based on laws of development and originality considered by Usooliyeen, the Mujtahid must actually be applied to the fundamentalist rule on the Shariah texts in order to derive the Shariahrulings from them, As he said: The evidence used by these provisions are the socalled " originality Fiqh", Then you are not aware that the branches are based on originality, those who do not understand how to deduction, it does not lead to the link between the provisions of the branches and evidence, that is originality Fiqh, there is no space for it, and he cannot divide them in any way, the sub-issues are wide, after its goals, known originality, organized conditions that does not know its originality, he doesn't have knowledge it.

The laws of inference and its rules can be divided into three main branches, all of which are attributed to Fiqh, as follows: Principles of Islamic jurisprudence, the rules of jurisprudence, and the legitimate purposes.

\section{Third: Caring of the heritage jurisprudence:}

The depth and originality of the heritage jurisprudence has important aspects of the best methodology in the application of the legitimacy texts of the incidents and justice issues experienced by our Fuqaha in their time, The approach followed by our first Fuqaha is generally reflected it, their attention to the legal texts combined, documented, the inference to its jurisprudence and provisions, In accordance with the principles and rules of inference, - as it is included in the work of the imams in the verses and Hadith of the rulings and its annotations, as well as the works of jurisprudence with different schools (Madh'hab), some jurists even sought to reveal the depth of the used methodology in the jurisprudence of applicants, they are unique in that works in "Takhreej alForo' Ala al-Usool " document the branches into assets, in which the rule of fundamentalism or jurisprudence is sometimes mentioned then branch branches jurisprudence to document it and whether this branching is compared to more than Madh'hab, As did Nizjani in his work "Takhreej al-Foro' Ala al-Usool " document the branches into assets and Honorable Talmansi in the "Muftah al-Usool" key assets, or it was the division within Madh'hab of a certain jurisprudence.

The modern renewed person may be needed in financial transactions to be a visionary in the doctrinal jurisprudential heritage, because it is full of practical applications on the legal texts for the purpose of deriving the provisions of financial transactions in their time, that is a practical training for the diligent and renewed in the late hurricane, the duty to do so is obligatory.

\section{Fourth: Caring of the incident jurisprudence:}

It has to be diligent in the jurisprudence of contemporary financial transactions to do the duty of verification of the reality of the transaction and what it is, especially if it is surrounded by the thumb and confusion in the real picture, the judgment on the thing is a branch of its conception, no matter how diligent the treatment in charge of it is in isolation from the realization as it is in fact it was an imbalance in the curriculum and the method of development, although it is right.

This requires that the diligent vision of the terminology of the people, in their contracts and conditions, their expressions and customs, to be detailed in detail, and a cautious restriction of releases of sentences to be careful not to ignore the question, so that the purpose of the fatwa is to be applied to what he desires and desires.(3)

\footnotetext{
${ }^{1} \mathrm{Al}-\mathrm{An}$ 'am - Verse 38

${ }^{2}$ An-Nahl - Verse 89.

${ }^{3}$ Renewal in Jurisprudence of Contemporary Financial Transactions, Dr. Riyadh Mansour Al-Khulaifi / Director General of the Office of the International Forensic Advisor for Consulting and External Legal Auditing - Kuwait.
} 


\section{The second topic: The conditions that must be met in the renewed person .}

There are conditions that should be provided in the renewed person agreed upon and some are different, but the agreed terms are as follows:

1. To be the renewed person of the surviving band: In other words, not to be a rerun of a perverted stray band, because it will renew the light of his deviation and away from religion, he may have been corrupted by corruption and deviant behavior.

2. The renewed person must have sufficient from religious knowledge: Some scholars are required to be diligent this condition can be adjusted and said: if the renewal was complete, the renewed person must be diligent at all, if the renewal is partial, it is sufficient for the renewed person to be diligent in the matter and the issue that will be renewed and this is the closest words to the right in the question of condition.

3. The renewed person must be renewed his high ambition: A word is "send" indicates that the renewed person (Allah sends), as stated in Hadith is neither lazy nor idle nor the owner of despicable worldly interests, but is a high-spirited, strong will and determination, he wakes up the night and gets tired during the day, looks at issues, and exert his effort, money and time in order to determine something of the religion of this nation, he is an activity, work, vitality, innovation, and creativity, what is beyond the renewal for the lazy and the passive.(1)

In his book "The Renewal of Islamic Thought," Adnan Muhammad says that the terms and conditions of the renewed person remind him of four conditions:

1. The renewed person should be known for his pure faith and the integrity of the curriculum. This can only be achieved if the renewal person of the Sunnis and the group walking on the approach of the Prophet peace be upon him and his companions.

2. To be a scholar, not even diligent, the most important tasks that should be undertaken by the renewal person face the problems that arise in every age and diligence in establishing legal solutions to them.

3. To include renewal of fields of thought and behavior in society, correcting the deviation from the most important tasks that should be performed by the renewed person, he corrects the understanding and ideas that cause the emergence of intellectual deviations, that entail serious behavioral deviations and spend it by reviving the flag and broadcasting it among the people, writing books, and other emerging means, and then eliminate traditions contrary to Sharia to reform people's behavior.

4. To benefit the people of his time, the renewed person is a period of time man to stretching a century, he is a beacon to awaken people, guide them, even the source of the new renewed person, this requires that the knowledge of the renewed person, the benefit of the people of his time, and leave his reform efforts a clear impact in the thinking of people and their behavior, this is done through his students and his loyal companions who continue his reform career by publishing his books and ideas. (2)

One of the most important conditions must be available in the renewed person to be a scholar of the Sunnis and the community not from the scholars of Sects, and increased his ability, his greatness, and his knowledge. The virtue of his renewal does not keep the knowledge or virtue, then how to renew or he is correct to call it a renewed term; he is steeped in heresies, needed, but legislator?"It is especially the tasks of renewal of the return of Islam pure net of all the elements extraneous to it, This does not happen unless the renewal person of the Sunnis and the community, walking on the approach of the Prophet peace be upon him and his companions, the survivor community Mansoura, which was described as a band of the seventythree band, and that it binds what the Prophet (peace and blessings of Allah be upon him) and his companions used in their Fiqh, methodology, and perceptions.(3)

Ibn al-Qayyim stated the Fatwa of the Mufti and Mujtahid, the most important of which are:

1. Peace of mind when doing the functions of slavery, because it inherits submission and reverence, and turning a blind eye.

The evidence for that is the saying of the Prophet (peace Allah be upon him) when he saw a man tampering with his beard during prayer: " if his heart is been submitted, his extremities are humble". (4)

2. Knowing people, this is a great asset needed by the Mufti and the ruler if he is not Faqeh in it or Faqeh in command and prohibition, then apply one to the other; Otherwise, it would have been spoiled more than to set aright. If he is not in the matter it is Faqih and he has the knowledge of

\footnotetext{
${ }^{(1)}$ Renewing religious discourse http://www.islamweb.net/ramadan/index.php

${ }^{(2)}$ Durar Sunni, "Renewed in Islamic thought", Adnan Mohammed imam, https://dorar.net/article/1434.

(3) Waqafat with renewal and renewed persons, Ramadan Al-Ghannam, Tanta University, the Islam way https://ar.islamway.net/article/33361. (4) Narrated by Ibn al-Mubarak in al-Azhid (p. 419) No. (1188), al-Murozi in (Ta'theem Amir assalah) 1/194 No. (151) and Abdul Razzaq 2/266 - 267 (3308-3309), Ibn AbiShaybah 2/289, All of them saw him arrested on Said bin Musayyib, al-Hakim al-Tirmidhi mentioned it in "NawaderAlosol" in the original forty-fifth century (p. 184), as mentioned by al-Bayhaqi in Sunan $2 / 285$ comments. See the singer about carrying books in travel (Matbo' Ma' Alahya') 1/150, and weak series 1/143 number (110), al-Ghaleel 2/ 92-93, No. 373.
} 
people to imagine him unjustly in his oppressed image and vice versa, eradication on false and reverse. (1)

The most important general issues that must be provided by the person responsible for the renewed person are:

1. Good memorization of the Holy Quran.

2. Keep some of Sahih Hadith as ten thousand Hadith, as an example.

3. Knowing the true belief and false beliefs.

4. Knowledge of the biography of a group of companions and followers and scholars and how their lives and their collection of science.

5. Understand the rules of language.

6. To observe the rules of jurisprudence, assets and readings. (2)

\section{The third topic}

The rules of renewal in the Islamic jurisprudence and two branches:

First branch: General controls of the jurisprudence renewal.

Second branch: Special controls of the renewed person.

First branch: General controls of the jurisprudence renewal.

The aim of the renewal Fiqh of social and cultural development, there are controls to be adhered to as not to satisfy the desire the renewal shall be for the purpose of which it is intended these controls are as follows:

1. Renewal is permissible in cases where ijtihad is permissible.

2. Be relevant to the reality of Muslims and then adjusts the reality in light of the text.

3. Practical application of the renewal.

4. Renewing the spirit of religion in the hearts of the nation.

Renewal is permissible in cases where ijtihad is permissible and demolition of what was his guide thoughtof the provisions of the case, whether false or proven or both, there isn't renewal in peremptory matters, such as:

The compulsory deed of prayer, fasting, Hajj, the prohibition of alcohol, pork, devouring usury, orphan money, lashing the Married man guilty of adultery, lashing the bachelor guilty of adultery, cutting off the hand of a thief, the distribution of the estate: "The share of a son was to be twice the share of a daughter", and other provisions of peremptory knowledge of the religion necessarily that united the nation.

This means taking into account the following matters:

First matter:It is not permissible to renew something that is not subject to jurisprudence and rulings that are not subject to three types of jurisprudence:

First Type: what knowledge of religion necessarily as a requirement of faith in Allah, worship Allah, prayer, pay Zakat, fast during Ramadan, and perform Hajj to the house (i.e., Ka'bah), the prohibition of usury, theft, murder and so on.

Second Type: The provisions in which it was stated absolute text and certainty such as:

Expiation for a broken oath in the verse of Al-Ma'idah: (Allah will not impose blame upon you for what is meaningless in your oaths, but He will impose blame upon you for [breaking] what you intended of oaths. So its expiation is the feeding of ten needy people from the average of that which you feed your [own] families or clothing them or the freeing of a slave.)(3) There is no difference in the amount of expiation in which there is no difference or renewal in the Sunnah.

Third Type:the practical provision that cannot tolerate the interpretation and the actual constant of the Prophet in the rituals of Hajj "Learn your rituals (of Hajj) from me" there is no way for renewal and the Prophet peace be upon him "offer your prayers in the way you saw me offering my prayers"(4)

Second matter: Replacing the renewal of opinion in which the field, this includes the text of the definitive evidence of significance, such as those who are the waiting period of divorce, the text of the verse: "Divorced women remain in waiting for three periods". (5)

The mujtahid must exert his power and effort in reaching out to identify the concerned persons from the text in which the text of the assertion is categorical, such as: The diligent must exert his power and effort in reaching the identification of any of the concerned parties of the text "For five camels and one sheep Sadaqah"6 the method of ijtihad and renewal in its hypocrisy is not in its significance because it is categorical.

"Whoever does not recite Al-Fatiha in his prayer, his prayer is invalid."(7)

It's not absolute, it is the news of the individual, it's proven path is not absolute, but it is hypothetical

\footnotetext{
${ }^{(1)}$ Durar Sunni /Sheikh Dr. Mansour Ibn Hamad Al-Eidihttps://er.islamway.netarticle/20807.

${ }^{(2)}$ From the rules of renewal of Islamic jurisprudence, Dr. Hassan Al Sayed Hamid Khattab. alhiwertodey.netLnodeL208.

${ }^{(3)}$ Surat Al-Maida: Verse 83

(4) Narrated by Bukhari and Muslim and narrated by Abu Dawood and Tirmidhi and women and Ibn Majah and Ahmad.

${ }^{(5)}$ Al-Baqarah: verse 228

6Jami' al-Tirmidhi, Hadith no. 564, Sunan al-Tirmidhi, Hadith no. 1344

${ }^{7}$ Bukhari - Bab al-athan Hadith 714
} 
significance, for the possibility of more than the meaning of potentially:

There is no prayer is complete except with al-Fatiha as understood by Hanafi and there is no valid prayer except with al-Fatiha as understood by Ash-shafiy.(1)

\section{Methods of Renewal of Contemporary Islamic Jurisprudence}

1. Salafi way: It is a return to the jurisprudence of FiqhSalaf, followers and abandon the jurisprudence of the doctrines, Dr. Muhammad Yusuf Musa wrote a book in (History of Islamic jurisprudence: a strong call to renew it by reference to its sources first).

Some of them classified books in the jurisprudence of the salaf such as: (Mo'jamFedih al-Salaf) of Professor Dr. Sheikh Mohammed Al-Montaser Al-Ketani, (Encyclopaedia "Mawso'at" of Ibrahim Al-Nakhai) of Professor Dr. RawasQalaji, and others as "Fiqh Omar", some of the renewal persons are incompatible the Fiqh of doctrines or misjudges their doctrines.

2. Selective Method or demagogy: is to choose the likes of desire and lust, and choose some judgments and neglect others that Islam is indivisible and judging this method as its predecessor is unjust.

3. The aggressive way: is an anti-Islamic jurisprudence, abandon the rich jurisprudential wealth recognized by senior jurists, and jurists in the contemporary world. A method of demolition, trying the alienation of rubes of their approach to make the legal text the last thing, and take according to their tendencies and desires what they see interest; they make the legal text in the end to seek refuge in reserve.So what is the value of divine legislation, especially when the text is not respected? Do they dare to ignore the provisions of positive law and ask the judges to ignore them? (2)

4. Approximate Method: The approximation of the jurisprudence of the positive law, as if the positive law the status of holiness, and Islamic jurisprudence without form and content, These are trying to interpret the texts of legitimacy interpretation away from the frankness of the text and its purpose, this reverses the situation; because positive law recognizes the reality of social relations to achieve stability regardless of religion and morality with reference to the fact that the laws of the situation is unstable, and they are subject to modification and change, and remains deficient in the opinion of its authors to reach the level of the high level of religion and morality, so how can we make these laws the original situation, and Islamic jurisprudence depending?

5. The method of renewing the moderate or balanced doctrine of moderation: that is accepted by shari'a, it is the goal of every Muslim committed to his religion, jealous of him, which is the intent of our research this method first preserves the constants of Sharia, the requirements for development shall be taken into account on the basis of sent interests, including general customs in accordance with the spirit of the text, and then there is no inertia to keep pace with evolution. Such as the phenomenon of Islamic banks and the attempt to expand and spread throughout the Arab world.3

\section{Models of modern renewal persons:}

Examples of contemporary scholars who have renewed the Islamic jurisprudence Dr. Jamal EddinAttia, a specialist in law from the University of Geneva, and the head of the law department at the Faculty of Sharia at the University of Qatar previously, he is currently the editor-in-chief of the well-known contemporary Muslim journal.

Dr. Attia presented his research entitled «Renewed jurisprudence desired», which opens with a sense of renewal, which he occupied for a long time, he had already written a memorandum to the Ministry of Awqaf and Islamic Affairs in Kuwait in late 1965, at the beginning of thinking about the Ministry of the draft encyclopedia jurisprudence and then re-published in a booklet entitled "Legacy of Islamic jurisprudence and the method of benefiting from it: On the Islamic and global levels »in 1967, this idea was then further elaborated, depth, and arranged on the rings in the Encyclopedia of jurisprudence in the magazine «Islamic consciousness» in April 1970 in May 1971.

Then re-drafted its complete and its disseminate them in a paper entitled "The Need for the Encyclopedia of Islamic Jurisprudence" in 1972, in the scientific research house in Kuwait.The Ministry of Awqaf in Kuwait has responded to the idea, the Encyclopedia of Jurisprudence, and used the late Professor Mustafa Zarqa expert of the Encyclopedia.Attiyahsaid that the call to renew the writing in Islamic jurisprudence is not new. This has been preceded by some senior professors such as Senhuri and Abdul QaderOdeh ... and others.

Dr. Wahba al-Zuhaili, a professor of jurisprudence at Damascus University, the author of the Encyclopedia known jurisprudence (Islamic jurisprudence and evidence), and the expert jurisprudential councils in Jeddah,

${ }^{1}$ Bukhari - Bab al-athan Hadith 714

(2) Renewal in the Islamic jurisprudence/ its methods and controls, Dr. Mohammed Abdulrahman al-Marashli / Majalet al-Moslim al-Mo'aser. http://almuslimalmuaser.org/index.php?option=com_k2\&view=item\&id=572:eltagded.

(3) The renewal of Islamic jurisprudence "al-Mubadarawa al-Ahjam", Abdul Rahman Haj Ibrahim

http://articles.islamweb.net/media/index.php?page=article\&lang=A\&id=273 
Mecca, India and America. Dr. Wahba al-Zuhaili wrote his research entitled "Renewing Islamic Jurisprudence" stressing in his introduction that the possible renewal in Islam does not stand before him development and progress.

The fourth topic: Sami Hmoud as a modern renewal person.

Dr. Sami Hassan Mahmoud, General Manager of Al Baraka Islamic Financial Research and Consultancy Center, is one of the most prominent renewal people in modern Islamic financial transactions. The title of his thesis was in his doctoral degree on 30/6/1976, which was entitled (the development of banking in accordance with Islamic law) (1)

It is his contribution that he prepared the preliminary draft of Provisional Law No. 13 of 1978, under the Jordanian Islamic Bank was established. One of the most prominent Islamic financial issues that have been diligent in selling Speculation for the purchase order is one of the financial transactions in the contemporary application of Sharia transactions. This transaction was defined as the Bank's execution of the contractor's request on the basis of the first purchase of the second payment by the bank in whole or in part, in exchange for the student's obligation to purchase what he ordered and according to the agreed profit at the beginning. This provision may be fully substantiated by the issuance of the permanent law of the Jordanian Islamic Bank, Law No. 62 of 1985. Speculation sale formula was popularized by the Islamic Development Bank in the field of foreign trade. This formula represents the predominant ratio of Islamic banks dealing with different locations and activities. It was natural that this formula was subjected to criticism and injury commensurate with thedegree of common if the sale of Speculation to the order to buy to the storms of speech right and often wrong.(2)

Among the efforts made by Dr. Sami Hassan Mahmoud is his attempt to apply speculation in Islamic banks, he believes that the application of speculation in the traditional binary form shown in the literature jurisprudence is not possible in the areas of collective investment.

On the banking system and in financial intermediation institutions in general, therefore his study focused on the proposal of a new form of speculation suitable for collective investment, multi-continuous and appropriate work of banking institutions, this new form has been called "common speculation" and has identified the people of this speculation in three teams:

First team: Investors group: They are the ones who illegally give money to "investment deposit holders" on the basis of directing to work speculative.

Second Team: The group of speculators: they are the ones who take the money alone to work with them according to their agreement.

Third Team:Joint Speculator: It is the person or entity whose task is to mediate between the two teams to achieve consistency and regularity in the flow of funds and give them to those wishing to the second team to work in it with the speculations held with each of them individually.

In this attempt, Dr. Mahmoud is seeking to benefit from the provisions of the common wage where it depends on the measurement to prove the existence of a common speculator.

Therefore, this attempt focused on developing the speculative contract to prove:

- Possibility multi-employer money and the worker in the process of speculation.

- Possibility of the existence to have a speculator to combine between two classes of money and a worker in one speculator.

- The possibility of a legal person acting as a speculator.

- Possibility to mix speculative money to invest in multiple fields.

- Possibility to specify and distribute profit without liquidating.

The contemporary jurisprudential opinions adopted by Dr. Sami Mahmoud:

It is permissible to deal with the requirement of the estimation of the forbidden element that has entered into the proceeds of the shares and the exclusion of it in the various benefits and not to use it in any form of utilization.

"That saying that it is forbidden to contribute to this type of companies leads to the withdrawal of Muslims from the economic life in the society to be unique to non-Muslims or the followers of the Muslims, and they manage without observing the provisions of the Sharia" as he said.(3)

One of the Islamic views that came out about the role of Speculation in achieving economic development.

Dr. Sami Hassan Mahmoud shows how to deal with this situation by saying:

"Speculation is constant speculation by nature does not stop or listen only if the whole work, this requires accordingly - treatment differs from the particular speculation that you can listen to at any time but we do not forget, nevertheless, we should be guided by the views of jurists that are important in this regard.

\footnotetext{
${ }^{(1)}$ Sale of Murabaha for the Purchase Order by Dr. Sami Hassan Mahmoud, General Manager of Al Baraka Islamic Financial Research and Consulting Center. Amman - The Hashemite Kingdom of Jordan 2/9285.

${ }^{(2)}$ Speculation and its practical applications in Islamic banks - Mohamed Abdel Moneim Abu Zaid p. $50,52$.

$\left({ }^{3}\right)$ Shares and bonds and their provisions in Islamic jurisprudence Dr. Ahmed bin Mohammed Al-Khalil, Assistant Professor in the Department of Jurisprudence at the University of Imam Muhammad bin Saud Islamic Qassim, Dar Ibn Al - Jawzi First Class Kingdom of Saudi Arabia p. 165
} 
Either in terms of how the profits are earned, the continuity of the work in speculation to unlimited makes it appropriate to be divided periodically, there is nothing wrong with it to be done annually as the joint stock companies do with the aim of achieving some kind of regularity and finding a way to make a periodic return to investors on specific dates, At the end of each year, profits are counted until they are divided by the percentage of funds allocated for investment whether it is money for investors alone or whether they were in common with the common speculator who is non-usury or any financial institution working in the field of investment in this new method. (1)

From the above, we find that Sami Mahmoud is one of the flags of innovation in the aspect of modern financial transactions, and he has diligence in this field and that many of the Islamicbanking institutions today on the diligence and renewal and knowledge, he is once again an economist in this age.

\section{Conclusion}

At the conclusion of this study, the researcher reached the following results:

1. The inclusion of Sharia on the general principles and rules valid for all time and place, which bring happiness to humans in the two homes.

2. Contemporary jurists have succeeded in rationalizing modern financial transactions through banks, finance companies and investment companies.

3. The renewal is divine guidance in this religion and scientists who renew this nation's religion, they are his deputies and heirs to the guidance of peace be upon him.

4. The rapid development of banking in the world and the emergence of many types of transactions and securities called for this fact that diligent Muslim scientists to do their duty towards their religion and legitimacy.

5. There are controls for the renewal and they are divided into two general controls and the other two special controls and this indicates that the renewal is not wide open.

6. The terms of the agreed upon renewal shall be from the surviving group and to have sufficient legal knowledge and to be of high interest.

7. The rules of the special the renewal person are many, the most important of which is the knowledge of the purposes of the Shari'a in the subject of the research, and the second is to know the conditions and customs of the people.

8. The rules of the special the renewal person should not be the one who sold the last of his assets and that he should not be one of the proponents of evolution.

9. The fixed provisions of the Shariah have no room for renewal, but the changing provisions are subject to renewal.

10. The provisions of religion, such as obligatory prayers, fasting, zakat and Hajj, are not renewed.

11. Methods of Modern Islamic Jurisprudence The Salafist Method, the Selective Method, the Aggressive Method, the Approximative Method and the Method of Renewal The moderate and balanced jurisprudence.

12. The most prominent modern models of modern scholars Dr. Jamal al-Din Atiyyah in his research, "Renewed jurisprudence desired" and Dr. Wahba al-Zuhaili in the writing of Islamic jurisprudence and evidence.

13. Dr. Sami Hassan Mahmoud, General Manager of Al Baraka Islamic Financial Research and Consultancy Center, is the owner of Ijtihad selling Murabaha to the buyer and the application of speculation in Islamic banks.

14. One of the contemporary jurisprudential opinions adopted by Dr. Sami Mahmoud, which prohibits dealing with the shares of companies with legitimate business in the original.

${ }^{1}$ Islamic banks between reality and hope, Dr. Qader Mohamed El - Taher Hassan Modern Library for Printing, Publishing \& Distribution Beirut Lebanon p.69 